\title{
From Elementary School Science to Graduate School Textbooks:
}

The Nuclear Chemistry Division at the Lawrence Livermore National Laboratory Attacks the Problem of Scientific Illiteracy

\author{
R. G. Lanier
}

Manuscript Date: Septémber 1, 1990 


\section{Preface}

On September 27 and 28, 1989, President George Bush met with the nation's governors in an "Education Summit" on the campus of the University of Virginia in Charlottesville, Virginia. The agenda focused on an overhaul of the nation's educational system. Underscoring the importance of this meeting was the fact that it represented only the third time in US history that a president has convened governors to discuss an important national issue. Previous such niectings were held in 1908 ('Theodore Rnosevelt; the ravaging of forests) and in 1933 (Franklin D. Roosevelt; the Depression). ${ }^{1}$ The general result of the summit was unanimous agreement that the present state of US education is in nerd of radical reform, and that we as a nation should "... establish clear, national performance goals, goals that will make us internationally competitive." - (These new goals for US education are tabulated in Appendix A)

Any national program which secks to achieve a better overall level of education for the general population must include an increased emphasis on developing scientific and technical literacy. In addition to promoting greater individual enrichment, such a program is critical for our survival as a science and technology leader in an increasingly complex world. The US Department of Energy (DOE), under the leadership of Adm. James D. Watkins (Ret.), has recognized this problem and has initiated action to effectively deal with it.

A rational strategy to enhance our national scientific literacy was developed at a "Math/Science Education Action Conference" co-chaired by Adm. Watkins and Nobel laureate Dr. Glenn T. Seaborg. ${ }^{3}$ The conference was held at the Lawrence Hall of Science, Berkeley, California on October 8-10, 1989, and was attended by nearly 250 scientists, educators, business executives and government leaders. The working participants established five concrete goals (Appendix B) and developed a strategy to achieve these goals by the year 2000, which was established as the target for accomplishing the goals so that this work would "... move in conjunction with those of the President and the Covernors." ${ }^{3}$ In articulating the strategy to attack the problem of scientific literacy, Adm. Watkins observed that the DOE has a collection of scientific laboratories, facilities and experts that are unparalleled and which "... have the potential to set a highly visible and creative example of educational collaboration for the Federal Covernment and the private sector." 3 He further noted that many of these activities "... have been little known for too long," and that it was time to move these activities "... out of the shadows..." 3 and inspire others with our example.

The present report serves to collect and itemize the contributions that the Nuclear Chemistry Division (NCD) of the Lawrence Livermore National Laboratory has made to science education during its recent past. The relevant data and their assembly into a hopefully coherent document came as a result several discussions held within the NCD immediately following the Berkeley "Math/Science Education Conference." We recognized that our Division had had considerable involvement in formal and informal science education activities long before the deficiencies in this area became a public concern. With the new current awareness about the needs in science education, it seemed appropriate to now bring these activities "out of the shadows" and offer them as an example of what can be accomplished by a group of dedicated individuals assisted by an enlichtened and aggressive management.

Abbreviated versions of the report have been circulated informally for various purposes. The present final version has been expanded somewhat, and contains several appendices and a reference list. I wish to thank Ken Marsh, NCD Deputy Division Leader, for suggesting that this report be written, and for his continued insistence on its completion. I also acknowledge the many direct and indirect contributors to the text, but take full responsibility for all errors of omission or commission. 


\section{Contents}

Preface

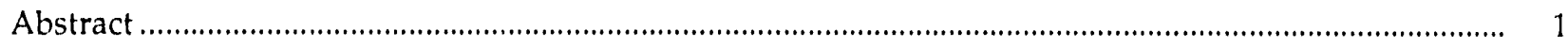

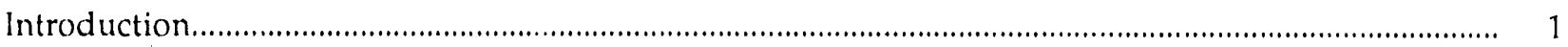

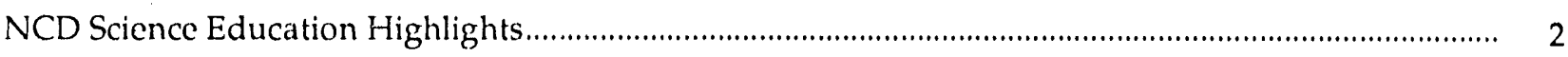

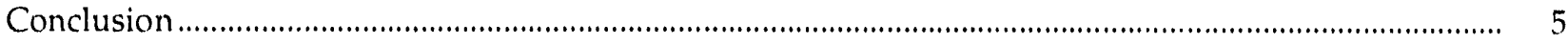

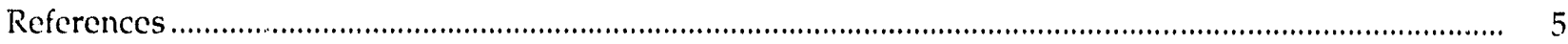

Appendix A-National Education Goals endorsed by President Bush's "Education Summit," Charlottesville, Virginia, September, 1989 ............................................................... 6

Appendix B-Science Education Goals endorsed by the "Math/Science

Education Action Conference," Berkeley, California, 1989.

Appendix C-Summary, Current Status, and Sources of Additional

Information for the Various Educational Programs and Initiatives

Mentioned in the Text 


\title{
From Elementary School Science to Graduate School Textbooks:
}

\author{
The Nuclear Chemistry Division at the \\ Lawrence Livermore National Laboratory \\ Attacks the Problem of Scientific Illiteracy
}

\begin{abstract}
The Nuclear Chemistry Division (NCD) at the Lawrence Livermore National Laboratory (LLNL) has a long history of using its resources to enhance the scientific literacy of students at virtually all educational levels, as well as providing for the continued scholarly development of its own staff. The Division has shown a particularly deep concern for motivating young scientific talent, and has a strong record of commitment toward educating and increasing the scientific skills of minorities and women. These activities are carried out by individual, group, or Division initiative and range from simple community involvement and classroom teaching to highly structured and specialized technical training.

This report collects and describes the official and unofficial educational activities that have been conducted in the Nuclear Chemistry Division at LLNL during the recent past. These activities serve as a model of what a few dedicated individuals and an enlightened management can contribute to the education of a new generation of scientists and engineers.
\end{abstract}

\section{Introduction}

On October 8-10, 1989, a Math/Science Education Action Conference was co-hosted by Adm. James D. Watkins, Secretary of Energy, and by Nobel laureate Dr. Glenn T. Seaborg, Chairman of the Lawrence Hall of Science, Berkeley, California. The purpose of this meeting was to find ways to revitalize science education in the United States. In addition to developing and endorsing five primary goals to achieve this revitalization, the participants set forth elements of a strategy to achieve these goals. The facilities and personnel at the National Laboratories were identified as essential ingredients to this activity.

By providing staff and facilities to manage, organize, and execute various educational activities, the NCD has been a major participant in several official and unofficial science education initiatives. Division members have been welcome technical leaders at the primary and secondary school level, where they have taught laboratory science and general scientific principles. The Division has further carried its scientific expertise to the college campus by participating in the direct classroom education of students and through research collaborations with professors. The Division also provides staff and facilities to foster and encourage the training of the new $\mathrm{PhD}$ and, via postdoctoral fellowships, provides him or her with an opportunity to pursue publishable basic or applied scientific research. Division personnel have also served as organizing chairmen and key committee staff for national and international scientific conferences. Finally, the Division provides encouragement and resources for mature staff to report work in scholarly review articles and to author scientific textbooks.

The Division's educational activity has been a significant factor in maintaining a vigorous, enthusiastic, and productive staff, one which is well respected in the international scientific community. These activities also reflect the Division's deep interest in and obligation towards transferring its skills and its experience to a new generation of technical leaders. 
Presented herein are highlights, by category, of the NCD educational activities. Table 1 largely identifies specific contributions by NCD personnel during a period encompassing the recent past (approximately 10 years ago or less), the present, and the very near future (less than 1 year). Appendix $C$ has been added to give some historical information on the programs referred to in the text. Sources of further information about individual participation are also noted.

\section{NCD Science Education Highlights}

- Educating Science Teachers: Division staff have demonstrated significant dedication to improving the scientific literacy of science teachers at all educational levels. For example, the LESSON program was instituted to educate primary school teachers in simple scientific principles and laboratory techniques. Several Division members contributed to authoring the laboratory manuals currently in use by the program and served as instructors in the initial sessions. The Division also designed and for several years hosted a Nuclear Chemistry Summer Institute sponsored by the Office of Equal Opportunity (OEO). Participants were professors from predominantly racially mixed colleges who were instructed in graduate-level nuclear chemistry. In addition, high school and college teachers, through sponsorship by various LLNL programs, are often involved in "hands-on" laboratory work supervised by Division staff.

- Science Education for Minorities: The NCD continues to provide educational opportunities for qualified minorities and women. Members of the Division are helping the Alabama A\&M University (AAMU) faculty to develop the curriculum for an advanced undergraduate nuclear chemistry course and to establish a PhD program in chemistry. This continues the ground work laid when several Division staff members developed and delivered at AAMU a complete lecture/laboratory advanced nuclear chemistry course during the 1988 Spring Quarter. In addition, NCD interactions with faculty in the Howard University Physics Department directly resulted in the establishment of a modern Mossbauer spectroscopy laboratory and a strong PhD educational program in this research area. NCD involvement was also an important factor in the University's successful competition for a \$480,000 NASA research grant.

Such interactions serve to more aggressively develop opportunities for qualified minorities and women. A "Memorandum of Understanding," which is a formal and general cooperative agreement between LLNL and AAMU, provides the basis for the Division's cooperation with AAMU. Howard University granted adjunct professorship status to members of the NCD who participated in the very successful Mossbauer research collaboration.

- Science Activities in the Classroom: Division staff of ten serve as instructors, as substitute or exchange teachers, and as individual tutors at community educational facilities. Recent experiences include teaching junior college level astronomy, substitute teaching of nuclear chemistry for university professors on sabbatical leave, tutoring math and chemistry io high school students, and preparing and teaching an introductory laboratory science course for primary school children. The "Magic Show," which impressively displays simple and well-known scientific phenomena to primary school children, has been hosted many times by Livision personnel.

- Summer Schools in Nuclear Chemistry: NCD personnel have played a crucial leadership role in developing, managing, and staffing "Summer Schools in Nuclear Chemistry." This is an undergraduate fellowship program which places gifted science students in an intensive six-week nuclear chemistry lecture/laboratory curriculum and assists them in finding continued summer employment at national laboratories, universities, or in industry. The program is sponsored by the American Chemical Society through its Division of Nuclear Chemistry and Technology. The responsibility for primary funding is borne by the US DOE Office of Energy Research. NCD personnel work in conjunction with staff at the San Jose State University to recruit qualified candidates and to teach school sessions. During the 1989 summer session, the program was expanded to include sessions at the Brookhaven National Laboratory and to involve staft at the State University of New York, Stony Brook. 
- Science Education Symposia: "Expanding Your Horizons in Math and Science-A Career Conference for $6^{\text {th }}-12^{\text {th }}$ Grade Young Women" and "Topics in Nuclear and Radiochemistry for College Curricula and High School Science Programs" are the titles of two important symposia that are being promoted and organized by individual NCD staff members. These activities seek to motivate and stimulate student interest in technical fields and to encourage young people to consider careers from opportunities among the scientific disciplines. The Division's past work with career motivation programs has been very encouraging. As a result, outside funding for this work is now being pursued more confidently, and there is increased enthusiasm for making such symposia available to a larger and more diverse student population.

- Undergraduate Science Education: The Division has been involved with the Associated Western Universities (AWU) Summer Undergraduate Participant Program for well over 20 years. The NCD provides staff and other facilities to administer and coordinate this program at LLNL. The AWU program allows selected undergraduate honor students to work for ten weeks on a science project of their own choosing. Students select a supervisor and science project from research proposals orally presented by LLNL staff members. Since the Division's initial involvement in 1968, approximately 350) students have been granted fellowships for summer work at LLNL. Well over 100 of these students chose to work with NCD staff members on NCD-sponsored research for their summer projects. Several AWU graduates have become Division employees.

- Graduate Science Education: The Division has an impressive record of successfully sponsoring the scientific research of individuals admitted to candidacy for masters or doctoral degrees. Division staff members supervise thesis research and serve as graduate advisors; some are adjunct professors. The University of California at Davis offers advanced degrees through its Department of Applied Science (DAS) on site at LLNL. Graduate students are available from DAS, but the majority come to the NCD through scientific collaborations between NCD staff and outside universities. During the 1988-89 academic year, two Division-supervised students received PhD degrees. At present, Division personnel are supervising the research of one MS and five PhD candidates.

- Post-Doctoral Science Education: Opportunities to use the unique facilities of LLNL and the NCD for research are offered to recently graduated science PhDs as funding levels permit. During their terms of appointment, participants refine their formal academic training by doing publishable basic or applied research in one of the Division's several ongoing scientific programs. Appointments are temporary and usually last for a term of two years. The Division currently funds nine young scientists for post-doctoral work.

- Other Academic and Scholarly Activities: Senior scientists in the NCD Division are well respected in the international scientific community. They are often called upon to organize or chair national or international conferences, to advise other scientific organizations, to write scholarly review articles and are sometimes commissioned to author highly technical textbooks. Such activities provide educational expertise to a highly specialized sector of the scientific community and are important for the general advance of any technical field. The International Conference on Nuclear Structure, Reactions and Symmetries (Dubrovnik, Yugoslavia, June 1986) and the Seventh International Symposium on Capture Gamma-Ray Spectroscopy and Related Topics (Asilomar, California, October 1990) are two examples of major topical conferences organized by Division personnel. A review article on "Coexistence in OddMass Nuclei"4 and graduate school textbooks entitled "An Introduction to Solid State Diffusion" 5 and "The Physical Chemistry of Solids" ${ }^{\prime \prime}$ are examples of recent scholarly writings. 
Table 1: Summary of involvement in science education activities by individual Nuclear Chemistry Division staff members.

\begin{tabular}{|c|c|}
\hline John Andrews: & OEO undergraduate summer research supervisor. \\
\hline Patricia Baisden: & $\begin{array}{l}\text { Organizer, ACS Undergraduate Fellowship Program "Summer Schools in Nuclear Chemistry," San Jose } \\
\text { State University and Brookhaven National Laboratory, and symposium on "Topics in Nuclear and } \\
\text { RadioChemistry for College Curricula and High School Science Programs" for Biennial Conference on } \\
\text { Chem. Ed.; member, NAS NRC Committee on Nuclear Engineering Ed.; participant, Adm. Walkins } \\
\text { Math/Science Ed. Conference; post-doctoral supervisor; lecturer, Alabama A\&M nuclear chemistry } \\
\text { course; "Magic Show" demonstrator. }\end{array}$ \\
\hline Richard Borg: & $\begin{array}{l}\text { Professor, U.C. Davis Department of Applied Sciences; Adjunct Professor, Howard University; invited } \\
\text { scholar, USSR Academy of Sciences; author of textbooks, An Introduction to Solid State Diffusion and } \\
\text { The Physical Chemistry of Solids; graduate thesis adviser. }\end{array}$ \\
\hline Robert Buddemeier: & $\begin{array}{l}\text { Graduate thesis adviser; guest lecturer, San Jose State University and the NSF Workshop for High } \\
\text { School Teachers, Sonoma State University; AWU student supervisor; lecturer, OEO Nuclear Chemistry } \\
\text { Summer Institute. }\end{array}$ \\
\hline David Camp: & $\begin{array}{l}\text { Adjunct Professor, University of California Medical School, San Francisco; instructor, University of } \\
\text { California, Davis, Las Positas College, Chabot College, and OEO Nuclear Chemistry Summer Institute; } \\
\text { organizer and lecturer, Alabama A\&M nuclear chemistry course; graduate research advisor. }\end{array}$ \\
\hline Daniel Decman: & Graduate research adviser; AWU student supervisor; post-doctoral supervisor. \\
\hline Arden Dougan: & $\begin{array}{l}\text { AWU student supervisor; "Magic Show" demonstrator, LLNL Science Education Center; guest teacher, } \\
\text { High School Science Teacher Exchange Program. }\end{array}$ \\
\hline Becky Failor: & $\begin{array}{l}\text { Organizer and member of National Board of Directors, "Expanding Your Hol zons in Science and } \\
\text { Mathematics Conference"; lecturer, Alabama A\&M nuclear chemistry course; "Magic Show" } \\
\text { demonstrator; lecturer, high school chemistry. }\end{array}$ \\
\hline David Gerlach: & Graduate research adviser. \\
\hline Patrick Grant: & Lecturer, OEO Nuclear Chemistry Summer Institute. \\
\hline Eugene Henry: & Graduate research adviser; AWU student supervisor. \\
\hline Nancy Henry: & Tutor, high school science and mathematics. \\
\hline Richard Hoff: & $\begin{array}{l}\text { Organizer and conference chairman, "Seventh International Symposium on Capture Gamma-Ray } \\
\text { Spectroscopy." }\end{array}$ \\
\hline Kenneth Hulet: & Invited scholar, USSR Academy of Sciences; post-doctoral supervisor. \\
\hline Jerry Landrum: & Lecturer and con tributor, LESSON program. \\
\hline kobert Lanier: & $\begin{array}{l}\text { Graduate research adviser, AWU student supervisor; lecturer, OEO Nuclear Chemistry Summer } \\
\text { Institute and Alabama A\&M nuclear chemistry course; contributor, LESSON program. }\end{array}$ \\
\hline Veronica Lanier: & $\begin{array}{l}\text { Instructor, elementary school Science Laboratory and Science Enrichment Program for gifted/talented } \\
\text { students; tutor, high school science and mathematics; contributor, "Expanding Your Horizons in } \\
\text { Science and Mathematics Conference"; member, Livermore Valley School District Science Advisory } \\
\text { Council. }\end{array}$ \\
\hline Doug Leich: & Lecturer, OEO Nuclear Chemistry Summer Institute; guest teacher, elementary school science. \\
\hline Kenneth Marsh: & $\begin{array}{l}\text { Lecturer, OEO Nuclear Chemistry Summer Institute; organizer and lecturer, Alabama A\&M nuclear } \\
\text { chemistry course. }\end{array}$ \\
\hline Richard Meyer: & $\begin{array}{l}\text { Chairman and organizer, "International Workshep on Nuclear Structure"; graduate research advisor; } \\
\text { LLNL coordinator and supervisor, AWU undergraduate program; lecturer, OEO Nuclear Chemistry } \\
\text { Summer Institute; post-doctoral supervisor. }\end{array}$ \\
\hline Mohammed Mustafa: & AWU student supervisor; lecturer, OEO Nuclear Chemistry Summer Institute. \\
\hline Neil Namboodiri: & AWU student supervisor. \\
\hline Sid Nicmeyer: & Post-docioral supervisor; graduate research supervisor; elementary school science teaching. \\
\hline Ruth Nuckolls: & $\begin{array}{l}\text { Docent, Sunol Regional Wilderness; guest speaker, LLNL Science Education Center; elementary school } \\
\text { laboratory demonstrations. }\end{array}$ \\
\hline Cynthia Palmer: & $\begin{array}{l}\text { Organizer, "Expanding Your Horizons in Science and Mathematics Conference"; tutor, high school } \\
\text { chemistry. }\end{array}$ \\
\hline Carl Poppe: & $\begin{array}{l}\text { Vice President, Board of Directors for The National Physical Science Consortium (NPSC); Laboratory } \\
\text { Advisory Board, AWL inc.; LLNL Coordinator, AWU undergraduate program; LLNL Continuing } \\
\text { Education Committee; lecturer, LLNL Continuing Education Committee; Steering Committee, AAMU } \\
\text { Memorandum of Understanding. }\end{array}$ \\
\hline Austin Prindle: & $\begin{array}{l}\text { Lecturer, OEO Nuclear Chemistry Summer Institute; contributor, LESSON program; elementary school } \\
\text { science teaching and laboratory demonstrations. }\end{array}$ \\
\hline JoAnn Regc: & $\begin{array}{l}\text { Contributor, LESSON program; elementary school science teaching and laboratory demonstrations; } \\
\text { contributor, "Expanding Your Horizons in Science and Mathematics Conference." }\end{array}$ \\
\hline Price Russ: & Graduate research adviser; post-doctoral supervisor; elementary school science teaching. \\
\hline Robert Silva: & Instructor, Alabama A\&M nuclear chemistry course; post-doctoral supervisor. \\
\hline
\end{tabular}


Table 1. (Continued)

\begin{tabular}{ll}
\hline Gordon Struble: & Graduate thesis adviso; guest lecturer, U.C. Department of Applied Science; organizer and lecturer, \\
& OEO Nuclear Chemistry Summer Institute; post-doctoral supervisor; LLNL Continuing Education \\
& Committec. \\
Richard Torres: & Lecturer, OEO Nuclear Chemistry Summer Institute. \\
John Wild: & Guest lecturer, San Jose State University; lecturer, OEO Nuclear Chemistry Simmer Institute, ACS \\
& Summer School San Jose State University, and Alabama A\&M nuclear chemistry course; contributor, \\
& LESSON program. \\
\hline
\end{tabular}

\section{Conclusion}

"What the future holds in store for individual human beings, the nation, and the world depends largely on the wisdom with which humans use science and technology. But that, in turn, depends on the character, distribution, and effectiveness of the education that people receive." The preceding quote is from an in-depth study done by the American Association for the Advancement of Science on the problem of US science education. ${ }^{7}$ It contains the implicit challenge that we as a nation, by choosing a "bright future," must provide the opportunities and mechanisms to enhance the scientific literacy of all individuals. The National Laboratories and their individual specialized divisions provide a unique mechanism for science education along a broad spectrum of disciplines, which in turn can be provided to a very diverse population of students and teachers. The experiences of the Nuclear Chemistry Division at the Lawrence Livermore National Laboratory provide splendid testimony of this fact.

\section{References}

1. "Hope and Dissent Blend in Education Conference," The New York Times, B 13 (September 28, 1989).

2. "Calling for an Overhaul," TIME Magazine, 60 (October 9, 1989).

3. Math/Science Education Action Conference Report, US Department of Energy, Washington, DC, DOE/S-(0)75 (May 199()).

4. K. Heyde, P. Van Isacker, M. Waroquier, J.L. Wood, and R.A. Meyer, "Coexistence in Odd-Mass Nuclei," Physics Reports 102 (5 \& 6), 393 (December 1983).

5. R.J. Borgand G.J. Dienes, Introduction to Solid State Diffusion (Academic Press, 1988), p. 360.

6. R.J. Borg and G. J. Dienes, The Physical Chemistry of Solids (Academic Press, in press).

7. Project 2061: SCIENCE for all Americans, Publication No. 89-01S, (American Association for the Advancement of Science, Inc., Washington, D.C. , 1989). 


\section{Appendix A \\ National Education Goals endorsed by President Bush's "Education Summit," Charlottesville, Virginia, September, 1989.}

1. Readiness for School: By the year 2000, all children in America will start school to learn.

2. High School Completion: By the year 2000, the high school graduation rate will increase to at least $90 \%$.

3. Student Achievement and Citizenship: By the year 2000, American students will leave grades four, eight and twelve having demonstrated competency in challenging subject matter including English, mathematics, science, history, and geography; and every school in America will insure that all students learn to use their minds well, so that they may be prepared for responsible citizenship, further learning, and prociuctive employment in a modern economy.

4. Science and Mathematics: By the year 2000, US students will be first in the world in science and mathematics achievement.

5. Adult Literacy and Lifelong Learning: By the year 2000, every adult American will be literate and will possess the knowledge and skills necessary to compete in a global economy and exercise the rights and responsibilities of citizenship.

6. Safe, Disciplined, and Drug-Free Schools: By the year 2000, every school in America will be free of drugs and violence and will offer a disciplined environment conducive to learning. 


\section{Appendix B \\ Science Education Goals endorsed by the "Math/Science Education Action Conference," Berkeley, California 1989}

1. Students: American elementary students will receive excellent preparation in mathematics and science in every grade.

2. Teachers: The Nation's mathematics and science teaching professionals will attain their rightful place as full-share partners in the scientific community and will become empowered to prepare this generation of children for lives of discovery in the 21st century.

3. Underrepresented Groups: Significantly greater numbers of female, minority, disabled, and disadvantaged students will complete a $\mathrm{K}-12$ education program, advance to the highest levels of science education, enter carcors in mathematics and science, and complete teaching programs in these ficlds.

4. Public Literacy: Citizens will, anderstand and derive excitement from confronting new frontiers in science, mathematics, and technology and will appreciate their potential for bettering our socicty and our world.

5. Competitive Work Furce: The Nation will have a diversified work force, competent in mathematics and science and equipped to meet the technological demands of the 21 st century. 


\section{Appendix C \\ Summary, Current Status, and Sources of Additional \\ Information for the Various Educational Programs and Initiatives Mentioned in the Text}

\section{LESSON Program}

The LESSON Program originated in 1969 with Dr. Manuel Perry of the Lawrence Livermore National Laboratory. It was initially run as a program to educate elementary and middle-school teaches $s$ in the basic elements of the biological sciences. The program uses a workshop format, with scientific personnel and equipment provided by LLNL, to provide "hands-on" instruction in basic scientific principles. The curriculum has evolved over the history of the program, and now includes a balanced mix of biology, chemistry and physics. Sessions include a maximum of 30 teachers, run for approximately 3 weeks. Participants earn three "Continuing Education" credits upon successful completion of the program. For more information on this program, contact: Dr. Richard Farnsworth, LESSON Program Coordinator, Office of Affirmative Action, L-716, Lawrence Livermore National !_aboratory, Livermore, CA 94550.

\section{The "Magic Show"}

The "Magic Show" originated with Dr. John Miskel of the LLNL Nuclear Chemistry Division. The "Mr. Wizard" format of the show dramatically demonstrates well-known physical and chemical phenomena, and is designed primarily to stimulate scientific curiosity in young children. The show is well-received by adults as well. It is a routine component of the Laboratory's Open House activities, and for many years was an exciting addition to the program at the LLNI "isitors Center. Volunteers prepare and deliver the show to audiences on request. For more information, contact Dr. Reoecca A. Failor, L-358, Lawrence Livermore National Laboratory, Livermore, CA 94550.

\section{Associated Western Universities (AWU)}

Associated Western Universities, Incorporated (AWU), a nonprofit organization incorporated in the state of Colorado and registered in the state of Utah, is funded almost entirely by the United States Department of Energy (DOE). The AWU program is a successor to a program that began with the US Atomic Energy Commission (AEC) in 1964, continued with the US Energy Research and Development Administration (ERDA) from January 1975, and, since October 1977, the US DOE. The Laboratory Cooperative Program, under these three successive agencies, was developed to help assure an adequate supply of manpower to solve national problems in science and technology. AWU is a contractor to US DOE that provides stipends and other appropriate remuneration to faculty and student participants who become involved in research projects at one of the cooperating laboratories or centers in the Western United States. For further information on AWU and its student/faculty programs contact Dr. Thomas Squires, Executive Director, Associated Western Universities Inc., 4190 South Highland Dr., Suite 211, Salt Lake City, UT 84124. 


\section{Expanding Your Horizons (EYH)}

"Expanding Your Horizons (EYH) in Science and Mathematics" conferences are designed to nurture girls' interest in science and math courses, and to encourage them to consider nontraditional career options. The conferences were originated in 19,76 by the Math/Science Network in Berkeley, California. (The Math/Science Network began in 1974. It is an informal group of women scientists and educators in the San Francisco Bay Areas who are concerned about the low level of female participation in mathenatics courses.) Since the origination of the EYH Conference Program, more than 140,000) students and 21,000 parents and educators have participated. Every year about 75 such workshops or meetings are conducted in 20 to 25 states. For lists of proposed conference sites or for other additional information contact Ms. Joy Wallace, Program Director, Math/Science Network, 2727 College Ave., Berkeley, CA 94705 .

\section{Summer Institute for Faculty (SIF)}

The program that was originally called the "OEO Summer Institute" in 1970 has evolved from a classroom lecture/laboratory experier ce to one which is potentially more decpiy enriching. The program is now known as the Summer Institute for Faculty (SIF) program, and is administered by the AA/EEO Programs Division of the LLNL Human Resources Department. The purpose of the SIF program is to enrich the research and education pregrams at colleges and universities with high enrollments of minorities, women, and handicapped students. Successful candidates are chosen from a pool of applicants who are faculty members from these colleges and universities. Currently the program consists of a nine-week work-study program that matches each successful applicant with an active LLNL scientist, and provides him/her with a work assignment which involves current scientific research. For further information on this program and other summer employment programs contact: Ms. Betty J. Havill, L-716, Employment Programs Assistant Manager, AA/EEO Progranes Division, Lawrence Livermore National Laboratory, Livermore, CA 94550.

\section{Nuclear Chemistry Summer School}

Nuclear Chemistry Summer School is a program sponsored by the American Chemical Society, and provides gifted undergraduate students with the opporiunity to study nuclear chemistry during a sixweek summer school. For more information on qualifications, scholarships, dates and sites contact Dr. Patricia Baisden, Nuclear Chemistry Division, L-231, Lawrence Livermore National Laboratory, Livermore, CA 94550. 

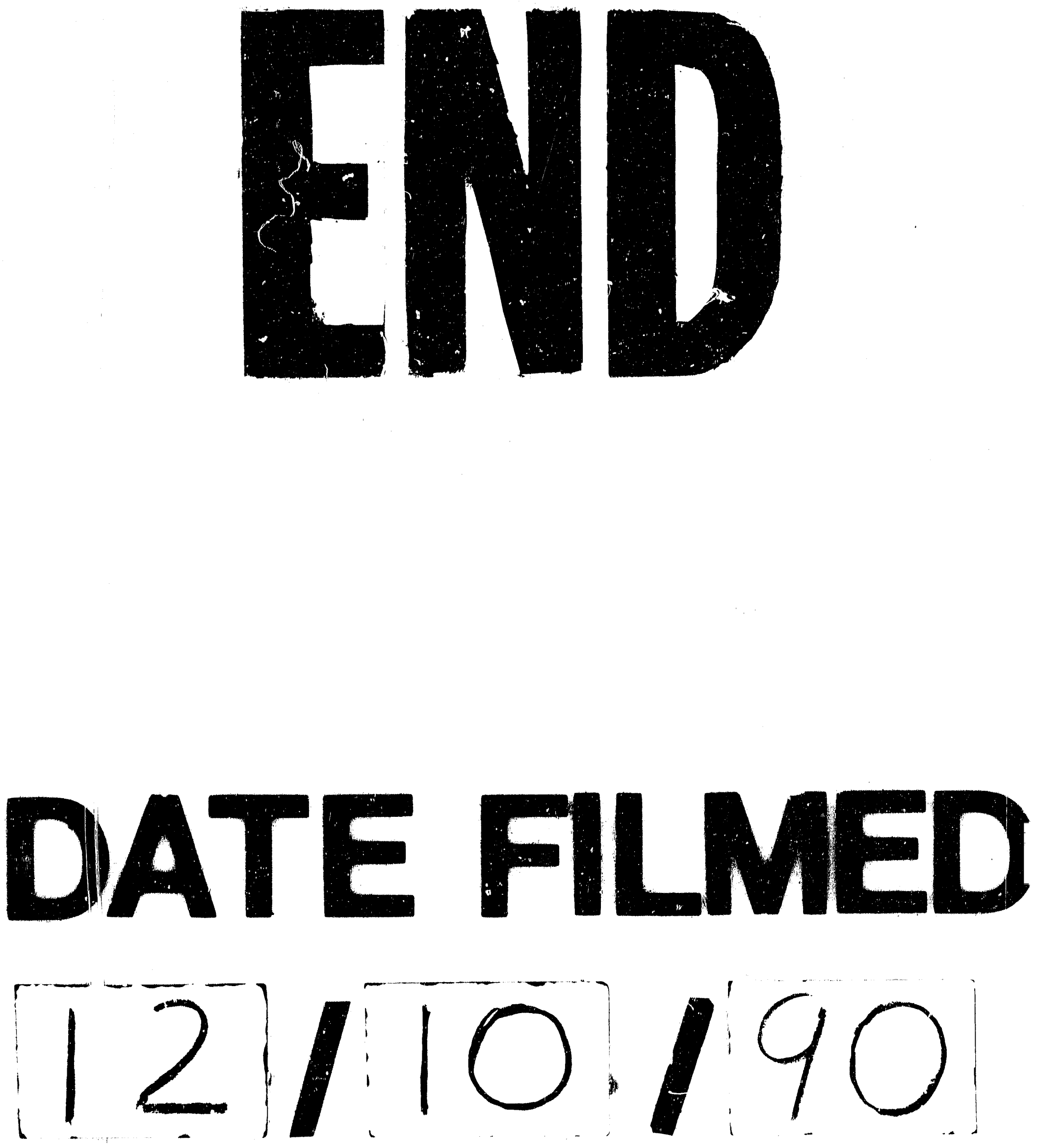
